\title{
Lessons from the Early Church for Today's Evangelical Christianity
}

\author{
Ervin Budiselić \\ Biblijski institut, Zagreb \\ ebudiselic@bizg.hr
}

UDK: 27-27; 27-72;279

Original scientific paper

Received: January, 2017

Accepted: March, 2017

\section{Abstract:}

Presuming that within Evangelical Christianity there is a crisis of biblical interpretation, this article seeks to address the issue, especially since Evangelicals view the existence of the church as closely connected to the proclamation of the Truth. Starting with a position that Evangelical hermeneutics is not born in a vacuum, but is the result of a historical process, the first part of the article introduces the problem of sola and solo scriptura, pointing out some problematic issues that need to be addressed. In the second part, the article discusses patristic hermeneutics, especially: a) the relationship between Scripture and tradition embodied in regula fidei and; $b$ ) theological presuppositions which gave birth to allegorical and literal interpretations of Scripture in Alexandria and Antioch. In the last part of the article, based on lessons from the patristic era, certain revisions of the Evangelical practice of the interpretation of Scripture are suggested. Particularly, Evangelicals may continue to hold the Bible as the single infallible source for Christian doctrine, continue to develop the historical-grammatical method particularly in respect to the issue of the analogy of faith in exegetical process, but also must recognize that the Bible cannot in toto play the role of the rule of faith or the analogy of faith. Something else must also come into play, and that "something" would definitely be the recovery of the patristic period "as a kind of doctrinal canon."

Key words: hermeneutics, rule of faith, Evangelical Christianity, patristic era, tradition, sola scriptura, solo scriptura. 


\section{Introduction}

Evangelical Christianity draws the great bulk of its identity from the Reformation. With its emphasis on Scripture, Evangelical Christianity often has an unfavorable relationship toward the history of the Christian church. Churches during the Reformation recognized that the true Christian church existed although it needed to be re-formed. This view has a more positive approach and is willing to learn from history because the Church has never ceased to exist. A more radical branch of the Reformation shared the view that, at some point in history, the church ceased to exist. Therefore, it needs to be re-created. That would mean that only with the inception of this or that particular church group, movement, or denomination, is the "true Christian church" somehow re-created. But what is that factor that determines the existence or termination of the church?

Traditionally, Evangelicals believe that the true church exists where the truth of God is preached. However, we cannot judge whether this or that group of believers in Jesus "make the church" until we establish proper parameters to define proper teaching and interpretation of Scripture. ${ }^{1}$ If we accept the claim that Protestantism, and more so Evangelical Christianity, is faced with a crisis of biblical interpretation, this situation is an existential question since, and rightly so, proper hermeneutics are tightly connected with the issue of the existence of the church. What would be a proper approach to this issue? If we adopt the radical outlook of church history that presupposes that "my group" has started from scratch, and that historical developments do not play any significant element in "my hermeneutics", we are closing the door for the resolution of this interpretation crisis. But if we adopt a positive outlook on church history, there is a chance that by studying the historical development of hermeneutics, we will gain a better understanding of the current situation and potentially find some solutions. If nothing else, we can learn some valuable lessons from the past.

In this article, we are going to follow the advice of Paul Hartog $(2007,84)$ who claims that "the contemporary church, as a needy patient, could humbly receive many healthy prescriptions at the hands of the patristic physicians." If we apply this advice to current Evangelicalism, we will observe in what way patristic exegesis can inform and speak to the current crisis in the Evangelical interpretation of Scripture.

In order to address this issue, in the first part, I will offer an introduction to the problem of sola and solo scriptura among Evangelicals, pointing out some

1 I am aware that such reasoning looks odd (to put it mildly) to more traditional churches such as the Roman Catholic or Orthodox Church, but I am writing this article from an Evangelical perspective. 
problematic issues that need to be addressed. In the second part, I will discuss some aspects of patristic hermeneutics such as: a) the relationship between Scripture and tradition embodied in regula fidei and; b) theological presuppositions which gave birth to allegorical and literal interpretations of Scripture in Alexandria and Antioch. Finally, in the last part, I will suggest certain revisions to the Evangelical practice of the interpretation of Scripture based on lessons learned from the patristic era. As we will see, patristic exegesis was not only shaped by its inheritance, but was also developed in a process of conflict and debate with various parties and heresies. I would like to argue that for Evangelicals today, it is particularly important to become aware of this historical development because the successes and failures of the past can inform the current situation in Evangelical hermeneutics.

\section{The Current Problem of the Evangelical Interpretation of Scripture: sola scriptura, solo scriptura and the Rule of Faith.}

\subsection{The Problem of Interpretation}

Evangelical Christianity was built on the inheritance of the Reformation and Protestantism whose main trust is the principle of sola scriptura. ${ }^{2}$ Sola scriptura does not imply the rejection of church traditions, but states that tradition can be accepted if it can be justified by Scripture. In that sense, sola scriptura is not a hermeneutical principle or rule for interpretation, but a theological position which argues for the primacy of Scripture. Although Evangelicals strongly affirm the primacy of Scripture, two things are particularly important to be pointed out:

a) Sola scriptura does not support the idea that each individual can, on its own, produce a quality and comprehensive interpretation. Although, in the beginning, reformers were optimistic in their belief that the ordinary believer could read and understand Scripture, but disagreements between Luther and Zwingli show that the clarity of Scripture is not always, nor in every aspect, evident. Therefore, even though every believer has a right to interpret Scripture, for difficult and ambiguous parts of Scripture, reformers offered two solutions: a) catechisms or books of instructions which served as filters through which individuals would be able to interpret Scripture; b) political hermeneutics in which city councils would occasionally provide authoritative theological interpretations and doctrines. In this

2 Sola scriptura is a principle which claims that the Holy Scripture/Bible is the only infallible source and standard of Christian doctrine, faith and life and, for that matter, that Scripture stands above the authority of the pope, councils or human opinions. All other authorities need to be subject to Scripture. 
way, reformers only replaced the authority of church tradition with the authority of secular authorities.

b) Sola scriptura does not resolve the problem of the authoritative interpretation of the Bible. It is one thing to say that the Bible is the only infallible source and standard of Christian doctrine, faith and life, but another thing is to know exactly what that authority teaches. Alister McGrath $(2001,157)$ is right on track when he says, "Texts need to be interpreted. There is little point in treating a certain text as authoritative or normative if there is serious disagreement concerning what that text means." Unfortunately, in their attempt to re-form or re-create right and pure doctrine, it is debatable as to what extent Protestant and Evangelical churches have been successful in providing authoritative interpretations of the Bible.

\subsection{From Problem to Solution}

Although sola scriptura is often accused of the promotion of subjective and individualistic Bible interpretations, the real problem in Evangelical Christianity, according to Keith Mathison $(2001,238)$, is not sola but solo scriptura:

\footnotetext{
"The modern Evangelical version of solo scriptura is nothing more than a new version of Tradition 0 . Instead of being defined as the sole infallible authority, the Bible is said to be the 'sole basis of authority'. Tradition is not allowed in any sense; the ecumenical creeds are virtually dismissed; and the Church is denied any real authority."
}

In other words, solo scriptura is a theological position according to which every individual has a right to interpret the Bible according to his or her preferences. Individual autonomy is highly valued and this position often produces "Jesus, Bible and $m e$ " Christianity. Contrary to that, sola scriptura accepts the concept of tradition in biblical interpretation, yet this relationship between the Bible and tradition in hermeneutics is not always clearly defined. The possible solution that is suggested for this hermeneutical puzzle is somewhat twofold because the solution lies in the application of regula fidei and/or the analogy of faith which represent a control mechanism for Bible interpretation, but the precise nature of this solution is likewise debatable. Here are two possible approaches: a) the Bible and the rule of faith and; b) the Bible is the rule of faith.

\subsubsection{The Bible and the Rule of Faith}

Theologians like Keith A. Mathison and Craig D. Allert suggest that although Scripture is the highest authority for Christian doctrine, life, faith and practice, it must be interpreted in accordance with regula fidei that originates from the tradition of the church. Naturally, this view presupposes that neither the church nor regula fidei were considered second supplementary sources of revelation (cf. 
Mathison 2007, 2). Mathison (2001, 151, 275) argues that, for the early church, there was no problem to comprehend Scripture and tradition together as a single source of God's revelation. Tradition was viewed as the content of doctrines that Christ gave to his church, whether in oral or written form. The apostolic tradition was gradually written into documents that today make up the New Testament canon, and these documents were interpreted in the hermeneutical context of the rule of faith. However, the key is to realize that, in the early church, there was no conflict between tradition and Scripture because the two were essentially the same. Allert $(2004,344)$ also argues against the common evangelical outlook which sounds something like this:

We are said to need the Bible to be the self-attesting, objective, and final revelation because there are 'sinful people' who pervert the Word of God time and time again. Again, we have the observation that there are proper interpretations and improper interpretations of the Bible. The only way to know which are proper and which are not is to appeal to the rule of faith - the Bible.

According to Allert $(2004,345)$, in this case, we have an impossible situation in which we are running in circles since the Bible simultaneously functions as object and assessor of interpretation. Using Tertullian as an example, Allert claims that for him, use of the rule of faith shows no reference to it being synonymous with the Bible since in a discussion against heretics, he "appeals to a tradition of proper doctrine that was delivered by Christ, spread by the Apostles and finally deposited in and safeguarded by the apostolic church. This tradition of proper doctrine was the rule, or standard, or right belief. For Tertullian, the rule of faith was the guide to a proper interpretation of the Scriptures, not the Bible itself."

\subsubsection{The Bible is the Rule of Faith}

Other Evangelical theologians reject the notion that the rule of faith has a connection to tradition, and confine it to the Bible. According to this view, the Bible should be our rule of faith because tradition, in the course of time, has become corrupt. Let us consider their arguments.

Speaking about the historical development of the rule of faith, $\mathrm{H}$. Wayne Johnson $(1988,69-70)$ explains that historically the rule of faith was first defined as faith confessed by the apostolic church and the compendium of true biblical teaching. After that, the rule became an ecclesiastical tool for controlling exegesis and a guarantee of harmonization with Catholic orthodoxy. In the Reformation, the rule of faith was defined as the compendium of what Scripture alone teaches which meant that exegesis should be done in accordance with the rest of Scripture rather than Catholic orthodoxy. Based on the association of the rule of faith with Catholic abuses, some Evangelicals would rather use the term "analogy of Scripture."

In conjunction with Johnson, Joseph F. Mitros (1968, 452-465) analyzes the 
development of the concept of "tradition". For Irenaeus and Tertullian, tradition was first of all the original message or the teaching of the apostles, but they also used the term to refer to the unwritten beliefs and doctrines in contrast with the Scriptures which they called the canon of truth and "rule of faith." This was possible because they viewed Scripture and tradition as two modes of transmission of the same original revelation and apostolic tradition. Furthermore, in the third and following centuries, the concept of tradition assumed a new meaning and began to include the totality of ecclesiastical life such as liturgy, creeds, the catechism instructions, the decisions of synods and councils, etc. Mitros also claims that in the third century, the concept of a purely oral, or an extra-scriptural, tradition emerged which supplied some information that was not in the Bible. However, this concept of tradition was primarily concerned with ancient customs and rites, and not doctrines- at least, not directly. Finally, Mitros (1968, 467-469) points out that in the early church, there was a trace of yet another form of tradition which claimed a secret extra scriptural tradition containing esoteric teaching allegedly coming from Christ with representatives such as Clement of Alexandria and Basil. Such an expansion of tradition which was open and allowed the emergence of a new revelation eventually led to the divinization of the papacy towards the end of the Middle Ages. He sees such a development of tradition as a result of the reintroduction of sensus plenior - a deeper spiritual meaning - the highly subjective and arbitrary method of the school of Alexandria for exegesis which has wrought havoc on Christian biblical scholarship.

Based on this view of tradition and its particular view of the Bible, John $\mathrm{H}$. Armstrong points out the following:

Protestant apologists have been historically quick to counter by insisting that Scripture alone is to be canon et regula fidei (i.e., "the canon and rule of faith"), because a rule which is insufficient, or incomplete and not final, is really no rule at all.... Only with a supreme, final and sufficient authority can the church itself have anything which is reliable, internally consistent, and never misleading. That authority has to be in Scripture alone.

Philip Schaff $(2007,7)$ argues for the same thing when he writes that in the Protestant system, the authority of symbols, as of all human compositions, is relative and limited, and therefore it should be subordinate to the Bible which he calls "the only infallible rule of the Christian faith and practice." Accordingly, "The Bible is of God; the Confession is man's answer to God's word. The Bible is the norma normans; the Confession the norma normata. The Bible is the rule of faith (regula fidei); the Confession is the rule of doctrine (regula doctrino)."

Walter Kaiser (1990,4) claims that "Few theological concepts have been more confusing and without clear development in the history of the church than this concept and the associated themes of regula fidei, unity of the Scripture, and 


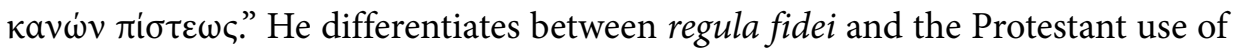
the analogy of faith by saying that:

the phrase 'analogy of faith' is not at all a common or frequently referred to principle in patristic and medieval writings. Instead, it appears under a plethora of names: the faith, the Catholic faith, the rule of truth, the preaching, the [order of] tradition, the measure of faith, and even the apostolic ecclesiastical or ancient institution of the church (Kaiser 1990, 6),

Furthermore, he adds that during the Reformation, among the reformers, there was a tendency to elevate subjective theological preferences and even church dogma as a supreme norm over what Scripture says. However, in theory, creeds of the church and articles of faith should be gained from, and grounded in, Scripture alone (cf. Kaiser 1990, 7). Hence, for him, the analogy of faith is not an imposition of one's theological system, confessions or doctrines onto Scripture, otherwise such reasoning would be circular. It is a hermeneutical principle which provides that Scripture is not subject to some absolute and external standard by which all Scripture is to be measured, or in other words, it was a mechanism that denied (corrupted) tradition the right to interpret Scripture (cf. Kaiser 1985, 69). In practice, that would mean that the analogy offaith operates under the assumption that Scripture interprets Scripture, namely that obscure texts or passages must be illuminated by other texts of Scripture whose meaning is clear (cf. Demarest B. $2001,58)$ because it presupposes the idea that Scripture was not announced with equal clarity everywhere (cf. Kaiser 1982, 173). Kaiser $(1990,10)$ is aware that different Protestant groups each have their own analogies of faith (Calvinists, Arminians, dispensationalists, covenantal theologians, charismatics, cessationists) and, for that matter, each have their own agenda regarding which passages are clear and which are not. But the crucial thing is that regula fidei is in actuality the analogy of faith (cf. Kaiser 1985, 69), so that "it is Scripture, not credos, confessions, or doctrinal statements, that sets the norms" (Kaiser 1990, 13).

In conclusion, we can say that Kaiser epitomizes those contemporary Evangelicals who argue that only based on Scripture can we determine which interpretation of the Scriptures is valid, arguing that the right exegetical method, ${ }^{3}$ and not some form of tradition, will lead us toward right theology. For that matter, he argues for the "analogy of Antecedent Scripture" in which "earlier citations, allusions, shared persons and events 'inform' and provide the background against which this new Word from God is heard" (Kaiser 1990, 13). Hence, if regula fidei or analogy offaith is an exegetical method, as Kaiser suggests, then we have to ask

3 Though Kaiser does not consider the analogy of faith to be an exegetical tool or part of the exegetical process. 
ourselves about the proper role of the analogy of faith in exegetical methodology. So today, in Evangelical hermeneutics, there is a continuous struggle to define the relationship between the analogy of faith and exegetical methodology, and we can recognize four exegetical patterns: a) "analogy of faith dictating exegesis," meaning that it defines the use of exegetical methods, and if exegetical results are contrary to the analogy, exegetical method must be changed; b) "analogy of faith as substitute for exegesis" where all exegesis is irrelevant if results contradict the orthodox analogy of faith; c) "analogy of faith as subsequent to exegesis" where the use of the analogy is postponed until after the exegetical process is completed and; d) "analogy of faith as one element of exegesis" where the text is approached with certain presuppositions which nevertheless, in the process of exegesis, become confirmed or changed (cf. Johnson 1988 70-80).

\section{Patristic Exegesis in the Context of Heresies}

Jeffrey W. Hargis $(1999,1)$ notices the following: “The fact that Christianity emerged within the cultural milieu of Roman Hellenism is no longer a matter of debate in the scholarship of early Christianity or of late antiquity." Such Hellenized culture was embedded with certain ideas and worldviews which shaped people's understanding, speech, way of life...in other words... their entire existence. Being "born" in such a culture, Christianity was eventually, for better or for worse, shaped by it. Christianity was also shaped by debates with contemporary Judaism over the significance of biblical promises and the interpretation of the Old Testament. They took the collection of Scriptures that belonged to a different religious group and made it their own which naturally produced conflict over interpretation - who is right and who is wrong? ${ }^{4}$ Furthermore, we must not overlook internal conflicts which produced various theological debates together with external conflicts with various philosophies (notably Gnosticism) which originated from a pagan background. All these past and contemporary factors shaped and formed patristic exegesis in its form and content.

As a result of all these factors in such dynamic and challenging surroundings, patristic exegesis grew and developed. As a result of this refinement and devel-

4 "Jews and Christians battled over the question, Who is the true Israel? Both religions clung to the Bible in Hebrew or Greek and interpreted it, each according to its own method. In the debates between them, the Bible was at the center: Whereas the Oral Law was unique to the Jews, Christianity saw its singularity in its belief in Jesus as the Messiah and his grace to humanity. Within this context, each of these religions turned to interpret the Bible and persuade each other, their own believers, and the pagan onlookers that it was the true Israel" (Hirshman, 1996, 22). 
opment, two things deserve our attention: a) the development and role of regual fidei in patristic exegesis and; b) methodological approaches to the interpretation of Scripture, namely, the problem of literal and allegorical interpretation embodied in the Alexandrian and Antiochian schools. Hence, in this part of the article, we will explore the development and role of regula fidei using Irenaeus as our primary example in this regard, and theological presuppositions which produced allegorical and literal interpretations of Scripture in the patristics.

\subsection{Regula fidei: Development and Role in the Context of Scripture and Tradition}

\subsubsection{Introduction}

The rule of faith, or regula fidei, can be understood as follows: the summary of the main points of the Christian faith; the essential message fixed by the gospel and the structure of Christian belief in God, reception of salvation in Christ, and experience of the Holy Spirit; a concise statement of early Christian public preaching and communal belief, a normative summary of the kerygma (cf. Hartog 2007, 65-66); basic theology of the church; sum content of the apostolic teaching expressing the key doctrines as well as the early structuring of the apostolic faith (cf. Bokedal 2013, 234-235); the hypothesis of the Scriptures; the essentials of Christianity (cf. Peckham 2008, 64).

Irenaeus was the first Christian theologian who spoke precisely about this concept which was developed as a result of the polemic with Gnosticism. In that sense, rule of faith was a historical product and it appears in two of his works: Against Heresies (I.10.1; I.22.1; III.4.1) and The Demonstration of the Apostolic Preaching (chap. 6). ${ }^{5}$ But "historicity" for Irenaeus does not mean that he was inventing something new. Tomas Bokedal $(2013,254)$ observes that the rule of faith was not a new concept for him:

Rather, it is largely a way for the church to point to previous formulations of the key elements of Christian belief, with particular reference to the source (God, Christ, and foe apostles) and the normative elements of its faith (Christological and two- or three-limbed confessions to the One God). The Rule of

5 For example, in AH I.10.1 Irenaeus writes, “...one God, the Father Almighty, Maker of heaven, and earth, and the sea, and all things that are in them; and in one Christ Jesus, the Son of God, who became incarnate for our salvation; and in the Holy Spirit, who proclaimed through the prophets the dispensations of God, and the advents, and the birth from a virgin, and the passion, and the resurrection from the dead, and the ascension into heaven in the flesh of the beloved Christ Jesus, our Lord, and His future manifestation from heaven in the glory of the Father 'to gather all things in one,' and to raise up anew all flesh of the whole human race, in order that to Christ Jesus, our Lord, and God, and Savior, and King, according to the will of the invisible Father... and that He should execute just judgment towards all..." 
Truth or the Rule of Faith in Irenaeus refers to truth or faith itself. As such, it sets out to express the central doctrines and early structuring of apostolic faith-often in a rather crystallized form and order.

Accordingly, Irenaeus traces the rule of faith back to the apostolic period through close association with the Christian profession of faith, baptism, catechetical teaching, Scripture, and early creedal formulation. On the other hand, the rule of faith had divine origins because Irenaeus had no doubt that the rule had come from God through the economy of the law, the prophets, Christ, the apostles and the church (cf. Osborn 2003, 147). Based on these introductory notes, we can now look more deeply at some of the issues that are associated with the origin, function and contribution of the rule of faith to the life of the church.

\subsubsection{The Context of Development and the Crisis of Authority}

The rule of faith was developed in the context of polemics with Gnosticism and, for that matter, it was a "reactive" document - produced as a reaction against something. This context determined its form and content. Hence, in order to understand this document, we need to understand the situation with which Irenaeus was faced. He was dealing with doctrine which taught many dualisms: theological dualism between God and demiurge; christological dualism between Christ and Jesus, Logos and savior, Christ above and Christ below; soteriological dualism which denied the universality of God's economy of salvation; scriptural dualism which separated the Old from the New Testament claiming that the God of the Old Testament was not the same as the God of the New Testament; ecclesiastical dualism according to which a distinction was made between simple believers and more spiritual believers; social dualism whereby some were said to be good and others evil by nature; practical dualism which was manifested either in rigorism attainable only by a few or the libertinism of the so-called superior men, and finally; metaphysical dualism opposing the world above to the world below, spirit to matter (cf. Vallée 1981, 20-22). Faced with such doctrines whose basic modus operandi was separation, Irenaeus confronted them with a different modus operandi: unification. But the question was: By what grounds or authority did he do that?

This problem is challenging because, as Simonetti $(1994,24)$ observes, Gnostics used the same interpretative method as Ireaneus to give their teachings scriptural authority. Since he did not have any clear hermeneutical principle of his own, the battle was fought, not over proper exegetical theory, but over content. Furthermore, Gnostics selectively used portions of Scripture and supplemented them with their own writings. At the same time, they claimed that many apostolic writings were corrupt or incorrect. There was also a debate over tradition 
wherein Irenaeus claimed that the genuine apostolic tradition was preserved by the church, but Gnostics claimed it was their own oral tradition which preserved genuine apostolic tradition.

In that context, the decisive factor for determining who was right and who was wrong was not to appeal to any particular exegetical method, Scripture or tradition, but as John McRay $(1967,5)$ claims - apostolicity:

The living voice of the apostles is no longer to be heard. Voices are rising within the very fold itself that challenge the unity of the Christian faith and present themselves as authoritative. There is no systematic theology worked out with which to meet these heresies. There is no canon of Scripture recognized by all as complete and authoritative to which appeal can be made. And yet it becomes quite obvious to Irenaeus that the apostles who founded the church and gave it its doctrinal statements must be brought to bear on these issues.

The logic of McRay's argument is that Irenaeus is among the first to deal with the question of real biblical exegesis due to the Gnostic perversion of Scripture. He did not have an established or universally accepted tradition which was sufficient enough to be convincing. He did not have a closed canon of Scripture to which appeal could be made, nor could he appeal to the authority of the bishops (presbyterial succession) without first showing that their authority was grounded on apostolic authority. Therefore, the solution for this conflict was to show that behind a particular tradition, Scripture or any authority of bishops stands apostolicity. In this way, he could argue that his tradition and interpretation of Scripture was valid and the Gnostics' was not (cf. McRay 1967, 8-9).

\subsubsection{The Relationship between Tradition and Scripture}

Closely connected with the issue of authority is the issue of the relationship between tradition and Scripture. In other words, the complexity of Irenaeus' usage of Scripture, tradition, apostolicity, the authority of presbyters, etc., inevitably raises the question of the relationship between Scripture and tradition. Accordingly, it is possible to claim that Irenaeus considered Scripture subordinate to tradition since tradition preserves and interprets Scripture thus making the church the norm. This implies an inadequacy of Scripture. Similarly, it can be argued that the church is the primary authority for Irenaeus, but only because it preserves the spirit of both testaments. It can be said that Scripture and tradition possess equal authority because both are the revelation of God and Irenaeus appeals to both in his argument. Neither is subordinate to the other because tradition is not employed as a hermeneutical principle (cf. McRay 4).

John C. Peckham (2008, 52-56) argues that for Irenaeus tradition paradosis refers to the transmission of apostolic doctrine which was passed down and preserved either in writing or orally. Hence, it does not mean adding or changing 
the original apostolic doctrine. But if we compare the number of references to tradition and Scripture, for example in Against Heresies, the main argument is that of Scripture: there are 629 allusions or citations from the Old Testament and 1,065 allusions or citations from the New Testament. Paradosis or tradition appears only thirty five times: four times refer to the Gnostic tradition; one time to a universal tradition (not Christian); nine times to the tradition of the elders in Matt 15; and finally, 21 times refer to tradition in the sense of Christian tradition. Accordingly, we can conclude that his main argument in the discussion against heretics is that of Scripture. But this does not mean that for Irenaeus Scripture was above tradition or vice versa because he identifies tradition as the "rule of truth", "faith", "teaching" and "preaching." He is able to name tradition with these labels because the content of each of them were the same due to the fact that each originated from the apostles and contain the same apostolic preaching (Ferguson $2010,13)$. Mitros $(1968,455)$ observes that though in terms of standard or norm, they are on the same level, Irenaeus refers to Scripture more extensively than tradition, and for that matter, believed it justifiable to consider Scripture "the last court of appeal."

\subsubsection{The Contribution of the Rule of Faith to the Life of the Church}

The rule of faith originated in the history of the church as a response to a particular problem, so it was limited in its scope and purpose. According to Rowan A. Greer $(1986,156-157)$, through the rule of faith Irenaeus gave to the church of his time, "a framework of interpretation that orders Christian transformations of the Hebrew Scriptures into a coherent pattern." It provided a principle of interpretation, but simultaneously these categories which guided the interpretation of Scripture were deduced from the Scripture itself.

Although the rule of faith functioned as a general framework for interpreting Scripture, Greer $(1986,176)$ notices that at a particular level, many problems remained. First, there is the ambiguity of Ireaneus' method of interpretation because he used typology in a somewhat allegorical way, and this ambiguity was manifested the best in the Alexandiran allegorical and Antiochian typological approaches to Scripture. Second, Irenaeus' definition of the Savior which was not fully resolved by him would be eventually addressed in Trinitarian and christological discussions in the following centuries. Third, Irenaeus said little about the meaning of scriptural interpretation as crucial to life. But Greer (1986, 197-199) also argues that the rule of faith by its designee was a negative rather than a positive principle. It excluded incorrect interpretations (what is not), but it did not require a correct one. Thus, one passage could have many interpretations that are valid because they do not contradict the rule of faith. Even though it did not settle the question of method or the issue of details in the theological, moral, and spiritual exposition of the Bible, it has limited the framework of interpretation 
and thus limited the context in which the quest for meaning can take place. With this conclusion, we turn our attention to the question of the methods of biblical interpretation.

\subsection{Literal and Allegorical Methodology of Interpretation: Alexandria and Antioch}

We have seen that patristic exegesis was partially a result of past influences that in various ways and levels have entered and shaped its form and content. However, building on the past, patristic exegesis was also being simultaneously developed as a result of contemporary issues, challenges and needs of the church. Accordingly, the rule of faith was developed predominantly as a response to Gnosticism, yet it did not resolve the challenge of biblical interpretation. It has provided a limited context or framework in which interpretation could be sought, but scriptural interpretation was still open for various methodologies and consequently, different and/or opposite theological conclusions. Notable examples of this hermeneutical development are the so-called Alexandrian and Antiochian schools of interpretation which we will now explore.

\subsubsection{The Alexandrian School}

The Alexandrian school is usually associated with the practice of allegorical interpretation with Origen as the most prominent representative of this school. This particular interpretive tradition was developed as a result of contact with Hellenized Judaism (Philo being one of that influence) and their polemic with the Gnostics. F. M. Young $(1999,25)$ claims that early Alexandrian Christianity seems to have been Gnostic in tendency since both Valentinus and Basilides came from Alexandria, and for the development of their system, they used allegory. This implies that the question was not so much a dispute over method since both Gnostics and Alexandrian Christians used the same methods, but over their theological convictions.

Influenced by Philo, Origen developed his own method of interpretation. He used the analogy of body, soul and spirit, claiming that Scripture has three senses: literal, moral and spiritual. The simple or ignorant Christian will stop at the knowledge that corresponds to the flesh of Scripture that is in a literal sense; the person who has made some progress may be edified by its soul; while the perfect will rise to a knowledge that comes from the spiritual sense of Scripture. However, Young (2003, 336-337) observes that this threefold classification of scriptural senses does not apply to three separate classes of believers. Rather, they correspond to different stages on a progressive journey to perfection.

The relationship between literal and spiritual-allegorical senses is a complex one. According to Origen, the literal meaning does not represent the ultimate goal of Scripture, but serves as a starting point towards a deeper spiritual mean- 
ing which escapes the majority of people (cf. Simonetti 1994, 42-43). Origen highlights two problems with the literal meaning: the historical reference of a narrative and the practice of legal and ritual rulings. He attributes the literal interpretation to the Jews who practice the law, claiming that Christians are not meant to take legal texts literally, but spiritually. He also understands some narratives such as God's planting of a tree like a farmer or walking in paradise in the cool of the day figuratively which indicate certain mysteries in the semblance of history and not actual events. On the other hand, he understands some narratives quite literally that we would regard as impossible (cf. Young 1999, 25).

We may assume that the spiritual-allegorical sense was used as a scapegoat for a quite practical reason: to eliminate passages too crudely anthropomorphic in their representation of divinity which disturbed educated Greeks and encouraged the rejection of the Old Testament by Gnostics. Hence, different parts of the Old Testament became subject to allegory: numbers and etymologies of Hebrew names, value details of the sacred texts such as names of animals and plants, etc. (cf. Simonetti 1994, 45-46). The common denominator for Origen was his understanding that in some instances the literal meaning of the Scripture was obscure due to grammatical forms, various rhetorical twists or the fact that some words could be used with different meanings (cf. Kannengiesser 2004, 171).

But that does not mean that allegorization was practiced without any restrictions. So Young $(1999,26)$ observes that in Alexandria, "the allegorical understanding of Scripture was based on a consistent methodology and used consistent correspondences, finding a coherent set of references to heavenly realities throughout the Scriptures," and Simonetti $(1994,46)$ argues that Origen was aware of the risk of arbitrariness inherent in such procedures, and therefore he tried to counter them by emphasizing that the literal sense is defective only in a few cases, arguing for the spiritual interpretation which would be connected to the literal meaning and confirmed by other scriptural passages.

\subsubsection{The Antiochene School}

Antiochenes in the fourth century challenged the allegorical approach adopted by the Alexandrians in the third. Hence, we may see this school as a reaction against Alexandrian allegory since their primary characteristic was emphasis on the literal and historical dimensions of the text. Because of that, some consider Antiochenes to be the precursors of modern historical exegesis (cf. Young 1999, 38).

Describing their methodology of interpretation, Robert C. Hill $(2005,151-$ 152) claims that Antiochenes simply insisted that an ancient text should be seen primarily in its own terms. Although they stressed the literal meaning of the texts, their procedure was not generally literalist or fundamentalist. Thus we must recognize the difference between the literal meaning and a literalist approach to the text: "The 'literal' may include the use of metaphor or other figures of speech, if 
this is the meaning which the purpose of the author and the linguistic context suggest," but "[a] literalist, on the other hand, is content to take a statement or work at face value without attempting or managing to divine the author's intention."

Although they share some common characteristics such as opposing historia (understood as the narrative logic of the text) to allegory, they also had their distinctive approaches. Theodore, for example, challenged some traditional prophetic and symbolic readings, and interpreted the prophets and psalms in relation to the events of Israel's history rather than as cryptic oracles concerning the Messiah. For Theodore, allegory was not permissible because it ignored the historia, but in some instances, based on historia, Scripture justifies the usage of theoria, or a higher spiritual sense, as in a traditional messianic interpretation of prophecies and psalms, and the mystical understanding of the Song of Songs (cf. Hanser \& Watson, 2003, 46; Young 1999, 39). But what was the difference between Alexandrian allegory and Antiochene theoria?

According to Young $(1999,39)$, allegory was a recognized figure of speech and the Antiochenes accepted allegory if it was indicated by the text. Hence, allegory was treated primarily as a figure of speech, not as an interpretive method. Literal interpretation was preferred and allegorical interpretation used only when the literal sense was impossible (cf. Hanser \& Watson 2003, 46). This implies that the problem for Antiochenes was not in the allegory, per se, but in a hermeneutic that misidentified and misapplied figures of speech.

Concretely, Antiochenes allowed for theoria which did not spiritualize the biblical narrative of creation, paradise, the fall, the gospel stories, the resurrection of the body or the kingdom of God (cf. Young 2003, 346). The key events in the foundation of faith should not be allegorized or spiritualized because they saw that as a threat to the foundation of the faith. And with this, we are now turning to attempt to reconstruct the fundamental differences that lie behind the conflict between these two schools.

\subsubsection{The Problem of Reconstruction}

Donald Fairbairn (2007, 1-2) notices that since the 1950's, patristic scholars have been undermining the model of understanding according to which patristic exegesis was divided into two competing and largely mutually exclusive schools, one based in Antioch and the other in Alexandria. The school in Antioch favored literal, historical exegesis, and the one in Alexandria favored allegorical exegesis. The practice of the allegorical method was ascribed to a Platonic way of thinking and Hellenistic presuppositions while the Antiochene school favored literal, historical exegesis as a result of interpreting the Bible from the vantage point of its own Semitic thought.

Fairbairn (2007, 2-3) sees three false assumptions in this model: first is that 
the Antiochene and Alexandrian schools were fairly uniform internally and were equally represented in the early church; second is that Alexandrian theologians ${ }^{6}$ were "bad" because they used the biblical text as a starting point for their philosophical speculation while Antiochene theologians ${ }^{7}$ were "good" because they took Scripture seriously, and; third is that the different theologies and homiletic emphases of Antioch and Alexandria were the result of different exegetical methods. He recognizes the fact that Alexandrians offered figurative interpretations of many passages in the Old Testament that the Antiochenes took more literally, and that Antiochenes focused their teaching and preaching on the moral progress of Christians, whereas Alexandrian preaching sometimes appears to be more abstract and philosophical in comparison. However, "to assert that these differences were produced by thoroughly distinct exegetical methods is to make an assumption, rather than to state a fact."

The notable example of this approach that Fairbairn criticizes is by Roger E. Olson (1999, 203-204) who argues that Antiochene theologians used the historical-literal-grammatical method and Alexandrians used the allegorical-spiritual method. He then concluded with the following statement: "How these two cities' approaches to biblical interpretation influenced their Christologies will become clearer as we explore that subject more directly." This implies precisely that which Fairbairn $(2007,6)$ criticizes: biblical interpretation influenced their theology and not vice versa. This line of reasoning is problematic because, according to Fairbairn, both schools used the same methods (literal and allegorical interpretations), and fathers from the same school, allegedly using the same method, would often come to vastly different conclusions. For that matter, we should pay more attention to reconstructing the controlling theological ideas that governed these two schools in their biblical interpretation, and not so much to ascribing different theological ideas to their different interpretative methodologies.

Frances Young (1999, 39; cf. Hanser \& Watson 2003, 44) claims that differences in interpretation between Alexandria and Antioch were not in their exegetical methods, but predominately in different hermeneutical methods: one stemming from rhetorical schools, the other from philosophical schools. They shared the common conviction that the literal wording of the text of the Bible points to a deeper meaning, but their conflict reflects a centuries-old struggle between the

6 Clement of Alexandria (second/third century), Origen (third century), Athanasius (fourth century), Didymus of Alexandria (fourth century), and Cyril of Alexandria (fifth century).

7 Paul of Samosata (third century), Eustathius of Antioch (fourth century), Diodore of Tarsus (fourth century), John Chrysostom (fourth/fifth century), Theodore of Mopsuestia (fourth/ fifth century), Nestorius (fifth century), John of Antioch (fifth century), and Theodore of Cyrus (fifth century). 
rhetorical and philosophical schools. Both schools followed the practices of the schools of grammar, rhetoric and philosophy: to methodikon and to historikon. The former included dealing with the linguistic issues of the text: etymologies of words, figures of speech and thought, tropes, and style; and the latter dealt with the background of the text to explain its content and references. However, philosophical schools also stressed the idea that the whole text has a hyponoia an under sense, or deeper sense. Accordingly they viewed words as codes to be discovered by cracking the codes, and not by following the sequence of the narrative argument.

In conclusion, the Alexandrians emphasized the to methodikon and philosophical aspects of their education and the Antiochenes emphasized to historikon and the grammatical and rhetorical aspects. Therefore, Young $(2003,352)$ concludes that "The difference lay not so much in exegetical method as in hermeneutical principles."

Some would argue that the real difference between these two schools lies in their different theological assumptions which then affected their interpretative methodologies and approaches. Simonetti (1994, 121-126) observes that general patristic hermeneutics was developed in the context of debates and controversies which resulted in the acceptance of certain doctrines and the condemnation of others. Thus, Scripture was used to support a particular view, and for that matter often taken out of its original context and considered in isolation. Therefore, theology, and not exegetical methods or hermeneutical principles, was responsible for the conflict between Alexandria and Antioch. In other words, the same exegetical procedure could produce different theological conclusions. Furthermore, Scripture does not present a homogeneous corpus of doctrine, but only scattered sporadic traces and indications that are often hard to harmonize, and this explains why quite contradictory doctrines could be set out on the same subject with proper scriptural support in the early church. Although opposite parties in a theological debate supported their doctrines with various scriptural passages, their overall orientation was often determined by more general presuppositions which governed their interpretation of Scripture. Hence, these presuppositions could have been a result of some earlier traditions, a development of controversy, a general view of scriptural passages or a different philosophical background. Based on this, Simonetti notices that Antiochene exegetes exhibit a materialist type of thought in contrast with the Alexandrian tendency to spiritualize with its obvious Platonic origins.

Fairbairn (2007, 10-11) similarly argues that different approaches to exegesis resulted from different ways of refuting the theological challenge of Arianism. In response, the Antiochenes argued that the one who suffered and died was not God the Son, and thus they could still affirm that God the Son was impassible 
and equal to the Father. Such a christological outlook divided the Logos from the man Jesus which in turn understood salvation as a human march, following Jesus, from the first age (one of imperfection and mortality) to the second age (one of perfect human life). Accordingly, the Old Testament was not read as prefiguring the New Testament, but as a document related to the first age. This naturally produced emphasis that was concerned with a historical and literal meaning of the Old Testament. On the other hand, Alexandrians refuted Arianism by affirming that it was God the Son who suffered in his humanity and not in his divine nature, per se. In their view of salvation, God the Logos himself was the active agent at every point of the earthly life of Jesus so that we might participate in him. But they made a distinction between what the Logos did that was in keeping with his divine nature and what he did that was in keeping with his newly adopted human way of living. Consequently, for them, the Old Testament pointed to Christ so their interpretation was more "spiritual" and not so concerned with the literalhistorical meaning.

Both parties shared these common ideas: a) a sharp separation between Creator and created, and God who radically transcends creaturely conditions, and; b) Christ had both a human and a divine nature (cf. Stang 2012, 533, 541). However, their worldviews shaped their theologies. Speaking about the Antiochene approach to the Old Testament, Hill $(2005,199-200)$ says that behind their approach to Scripture lies a particular worldview:

In all these areas of thought and life can be seen an emphasis on the humanwithout denial of the divine-as if to offset a real danger of its being minimized and obliterated. The human author of Old Testament texts and his factual situation cannot be bypassed in a process of moving-arbitrarily - to a range of spiritual meanings; an elevated meaning is permissible in texts on the proviso that continuity be maintained with the factual; the concreteness of the language of obscure texts and the crassness of the conduct described there are a necessary implication of the incarnation of the Word in Scripture.

The same thing can be said about the Alexandrian approach to Scripture:

For Origen the Platonist, both the created order and the text of Scripture were symbolic of the eternal world of spiritual realities. Symbols and types he understood in terms of something standing for something else, so that the words of Scripture became a kind of code to be cracked by allegorical reading. The dianoia, the real meaning, was veiled - that was the intent of the Spirit (Young 2003, 351).

In conclusion, we can say that the way these two schools understood christology shaped their soteriology, their understanding of the Old Testament, and finally their usage of exegetical methods. 


\section{Concluding Reflections: Revision of the Evangelical Practice of the Interpretation of Scripture}

We cannot turn the wheel of history, but we can study it, reflect upon it, and try to deduce and apply the wisdom of past generations to our current situation. Evangelical Christianity, for the most part, is not sensitive to the historical development of Christianity. It is probably not an exaggeration to say that the majority of Evangelical Christians believe that outside of the first church of the New Testament, Christianity has started with their own generation, and no one else, or maybe just a few individuals in all of church history understood what Christianity is really all about. However, we cannot escape the reality that what we are today is a result of historical development. Even the heritage that Evangelicals value the most - the Bible - is itself a product of history. Many other things that we believe and practice are also a result of historical development.

To some extent, the way Evangelicals interpret Scripture is a product of historical development. Reacting to what they perceived as a misuse of Scripture by the Roman Catholic Church, Reformers sought to purify church doctrine by appealing to Scripture, making it the sole infallible standard for Christian faith and practice. In all that, they allowed space for church tradition, but in order to be accepted, it had to be grounded in Scripture. A few hundred years later, building on the Reformation heritage, the majority of Evangelical Christians have lost their connection with the past turning sola scriptura into solo scriptura. As a result, an individualistic approach to the Bible (Jesus -Bible and me), anti-traditionalism and a free-church tradition produced a "multitude of conflicting versions of the faith" (cf. Wade 2001). The question is how Evangelical Christianity can reestablish its connection with the past, and revise its doctrine and practice without losing its orthodoxy. In conjunction with that is the question of how reflection on the past can inform our present.

Answers to these questions are not simple. Notably, the situation in the patristic era concerning the relationship between Scripture and tradition is not the same as today. In this regard, Peckham $(2008,70)$ summarizes the sentiment of many Evangelicals regarding the issue of Scripture and tradition:

However, there are large differences between the situation of Irenaeus and the present day. A few generations removed from the apostles is a much different context than 2,000 years removed. With such a wide gap from the apostles themselves, the most accurate record of their teachings is not found in humans but in the Scriptures. The meticulous preservation of NT writings is well attested in scholarship. Thus, I have confidence that the NT Scriptures contain the accurate teachings of the apostles and of their teacher, Jesus. Accordingly, there would be no need of an alternate authority to function as a witness to these writings, as was the case for Irenaeus. I believe the Scriptures may speak 
for themselves and the successors of the apostles are those who uphold the apostolic teachings contained in the Scriptures. In this way it is incumbent upon all Christian traditions to revisit these original apostolic teachings and continually put our own traditions to the test.

Since tradition has been compromised, the only solution is to turn to Scripture, thus making Scripture simultaneously the only infallible authority and the guiding framework for interpretation - the rule of faith. The result of such an approach is a "multitude of conflicting versions of the faith." However, we have seen that in the patristic era, we had a general theological framework - the rule of faith which allowed for one passage to have many interpretations that are valid. We have the same situation among Evangelicals today. The general framework is the same, the overall salvation narrative is the same, but we have different theological conclusions, interpretations and applications of the various theological details of this grand narrative.

Although Scripture is, for Evangelicals, the only infallible source of apostolic tradition today, we should not neglect the past for several reasons: a) the teachings of the church fathers provide a wonderful resource for understanding our faith; b) patristics can remind us of the central truths of Christianity which will give us a basis for evaluating doctrinal teachings today; c) by seeing what is most important, we can work to correct the disunity in the church; d) knowing our past and heritage gives us a sense of being a part of something big, something that stretches beyond the world we see (cf. Wade 2001). Therefore, even though we do not accept everything that happened in church history, neither should we reject it completely.

Finally, Evangelicals today, like the church in the first few centuries and Judaism of Jesus' time, is faced with the challenge of applying Scripture to current situations: Judaism had developed many rules and approaches to do that; Jesus and the New Testament writers were doing that; the church of the first few centuries was doing that as well as Protestants. In this regard, John L. Thompson (2013, 191) says the following:

And despite the common belief that Protestant interpreters despised allegory, it is truer to say that they despised capricious allegory. Scripture itself warranted too many types and allegories and analogies for them to think these exegetical moves or strategies were utterly off limits....Even then, the Reformers liked to think of themselves as models of discretion in their use of allegory, in that their allegories or analogies were never capricious, always suggested by the text, and focused almost exclusively on Christ or his church.

Although Evangelicals claim to adhere to and champion the historical-grammatical method, in practice, especially in their sermons, we can find many examples of allegories, typologies, spiritual analogies, etc., of the Old and New Testaments. 
What shall we do with the Old Testament? Can we reproduce the exegetical approach of the New Testament authors? Because of past abuses, many will decline such an attempt while others would argue that we have clear guidelines and safeguards to find Christ in the Old Testament exactly as the New Testament does (cf. Swanson, 1996). The separate question is the spiritualization and allegorization of the New Testament which is responsible for producing numerous new doctrines among Evangelicals. Anyhow, the choice is not an easy one because where must one draw the line ${ }^{8}$ The problem is that Evangelicals have no external rule of faith; they reject church magisterium, and appealing to church tradition is helpful only to a point because of its corruption. So we have two options.

We may endlessly run in circles if we continue to hold the Bible as the single infallible source for Christian doctrine and the "judge" of our biblical interpretation (rule of faith). However, if we have two different/opposing interpretations of a particular doctrine that are both supported by scriptural evidence, obviously, someone is wrong. Again, who can determine which party misused the Bible? Claiming that the Bible itself makes the determination because it is perspicuous (cf. Allert 2004, 342) is, in my opinion, naïve.

Or, a better option would be this: we may continue to hold the Bible as the single infallible source for Christian doctrine, continue to develop our historicalgrammatical method particularly in respect to the issue of the analogy of faith in exegetical process (article from H. Wayne Johnson), but also recognize that the Bible cannot in toto play the role of the rule of faith or the analogy of faith as Protestants would call it. Something else must also come into play. The reason for this is that before there was a closed New Testament canon, there was a church, and at the beginning of this church, there were apostles, and prior to them, Jesus. This something else would definitely be the recovery of the patristic period "as a kind of doctrinal canon" (Williams 1999, 139), a period which is "foundational to

8 For example, Graeme Goldsworthy (2001) says this: "Failure to recognize the unity of Scripture led some of the early expositors to follow false trails. The emergence of the allegorical method of interpretation in the early church provides a good example. Because much of the Old Testament was seen as unhelpful or sub-Christian, the only way to save it for Christian use was to distinguish a hidden 'spiritual' sense, concealed behind the natural meaning. Allegory seemed to be a legitimate method of interpretation because it was controlled by the content of the New Testament or, later on, by church dogma. What was lacking, however, was the kind of control the New Testament itself applied when it used the Old Testament....In the Middle Ages, the logic was taken a step further. Not only was the 'unhelpful' natural sense of the Old Testament given its spiritual sense from the natural sense of the New Testament. Even the natural sense of the New Testament was seen to require its own spiritual interpretation, which was found in the tradition of the church. Thus, authority now lay, not in the natural meaning of the canon of Scripture, but in the teachings of the church as it interpreted the spiritual meaning according to its own dogma." 
the Christian faith in normative ways that no other period of the church's history can claim" (Williams 2006, 24).

I am not suggesting that everything the patristic period produced was doctrinally sound and correct, nor do I see this quest as something which undermines the doctrine of sola scriptura and Scripture's perspicuity. On the contrary, in discovering not only their Protestant but also Catholic roots, Evangelicals can only gain a better perspective for tomorrow and learn some valuable lessons.

\section{Literature:}

Allert, Craig D. 2004. What Are We Trying to Conserve?: Evangelicalism and Sola Scriptura. The Evangelical Quarterly 76.4: 327-348.

Armstrong, John H. The Authority of Scripture. The Highway.org. http://www. thehighway.com/Sola_Scriptura_Armstrong.html.

Bokedal, Tomas. 2013. The Rule of Faith: Tracing Its Origins. Journal of Theological Interpretation 7/2: 233-255.

Fairbairn, Donald. 2007. Patristic Exegesis and Theology: The Cart and the Horse. Westminster Theological Journal 69/1: 1-19.

Ferguson, Everett. 2003. Backgrounds of Early Christianity. Grand Rapids: Wm. B. Eerdmans Publishing Company.

Goldsworthy, Graeme. 2001. Is the Old Testament for Christians? Monergism. http://www.monergism.com/thethreshold/articles/onsite/otchristians.html

Greer, Rowan A. 1986. Early Biblical Interpretation. Philadelphia: Westminster John Knox Press.

Hanser, Alan J. \& Watson, Duane F. 2003. Introduction and Overview. In: Alan J. Hanser \& Duane F. Watson, eds. A History of Biblical Interpretation. Volume 1, The Ancient Period, 1-54. Grand Rapids: Wm. B. Eerdmans Publishing Company.

Hargis, Jeffrey W. 1999. Against the Christians: The Rise of Early Anti-Christian Polemic. New York: Peter Lang.

Hartog, Paul. 2007. The "Rule of Faith" and Patristic Biblical Exegesis. Trinity Journal Volume 28: 65-86.

Hill, Robert C. 2005. Reading the Old Testament in Antioch. Leiden: Brill.

Hirshman, Marc. 1996. A Rivalry of Genius Jewish and Christian Biblical Interpretation in Late Antiquity. Albany: State University of New York Press.

Johnson, Wayne H. 1988. The "Analogy of Faith" and Exegetical Methodology: A Preliminary Discussion on Relationships. Journal of the Evangelical 
Theological Society 31/1: 69-70.

Kaiser, Walter. 1982. Evangelical Hermeneutics: Restatement, Advance or Retreat from the Reformation. Concordia Theological Quarterly 46/2-3: 167-180.

Kaiser, Walter. 1985. The Uses of the Old Testament in the New. Chicago: Moody Press.

Kaiser, Walter. 1990. Hermeneutics and the Theological Task. Trinity Journal 12:3-14.

Kannengiesser, Charles. 2004. Handbook of Patristic Exegesis: The Bible in Ancient Christianity. Leiden: Brill.

Mathison, Keith. 2001. The Shape of Sola Scriptura. Moscow: Canon Press.

McGrath, Alister E. 2001. Reformation Thought: An Introduction. Oxford: Blackwell Publishing.

McRay, John. 1967. Scripture and Tradition in Irenaeus. Restoration Quarterly 10/1: 1- 11 .

Mitros, Joseph F. 1968. The Norm of Faith in the Patristic Age. Theological Studies 29/3: 444-471.

Osborn, Eric. 2003. Irenaeus of Lyons. Cambridge: Cambridge University Press.

Peckham, John C. 2008. Epistemological Authority In The Polemic Of Irenaeus. Didaskalia 19/1: 51-70.

Schaff, Philip. 2007. The Creeds of Christendom: History of the Creeds, Volume I, Part I. New York: Cosimo Publications.

Simonetti, Manilo. 1994. Biblical Interpretation in the Early Church. Edinburgh: T\&T Clark.

Stang, Charles M. 2012. The Two 'I's of Christ: Revisiting the Christological Controversy. Anglican Theological Review 94/3: 529-547.

Swanson, Scott A. 1996. Can We Reproduce The Exegesis Of The New Testament? Why Are We Still Asking? Trinity Journal 17/1: 67-76.

Thompson, John L. 2013. At the Margins of the Rule of Faith: Reflections on the Reception History of Problematic Texts and Themes. Journal of Theological Interpretation 7/2: 187-198.

Vallée, Gérard. 1981. A study in anti-Gnostic polemics: Irenaeus, Hippolytus, and Epiphanius. Waterloo: Wilfrid Laurier University Press.

Wade, Rick. 2001. Introduction: Evangelicals and Tradition. Probe Ministries. https://www.probe.org/Scripture-and-tradition-in-the-early-church/.

Williams, Daniel H. 1999. Retrieving the Tradition and Renewing Evangelicalism: A Primer for Suspicious Protestants. Grand Rapids: Wm. B. Eerdmans Publishing Company. 
Williams, Daniel H. 2006. Tradition, Scripture, and Interpretation: A Sourcebook of the Ancient Church. Grand Rapids: Baker Academic.

Young, F. M. 1999. “Antiochene School”. In: John H. Hayes, ed. Dictionary of Biblical Interpretation, 38-40. Abingdon Press. Nashville.

Young, F. M. 1999. “Alexandrian School.” In: John H. Hayes, ed. Dictionary of Biblical Interpretation, 25-26. Abingdon Press. Nashville.

Young, F. M. 2003. Alexandrian and Antiochene Exegesis. In: Alan J. Hauser \& Duane F. Watson, eds. A History of Biblical Interpretation: Volume 1, The Ancient Period, 334-354. Grand Rapids: Wm. B. Eerdmans Publishing Company.

\title{
Ervin Budiselić
}

\section{Pouke iz rane Crkve za današnje evanđeosko kršćanstvo}

\begin{abstract}
Sažetak
Pretpostavljajući da u evanđeoskom kršćanstvu postoji kriza biblijskog tumačenja, ovaj članak nastoji ukazati na tu problematiku, posebice zato što je za evanđeosko kršćanstvo postojanje Crkve usko vezano uz navještaj Istine. Polazeći od pozicije da evanđeoska hermeneutika nije rođena u vakuumu, već je rezultat povijesnog procesa, u prvome dijelu članka uvodno se analizira problematika između sola i solo scripture, i ističu se neka problematična pitanja na koja treba obratiti pozornost. $U$ drugome dijelu članak se bavi hermeneutikom u partističkom razdoblju, posebice: a) odnosom između Pisma i tradicije, koje je utjelovljeno u pravilu vjere (regula fidei); b) teološkim pretpostavkama koje su dovele do alegorijskog i doslovnog tumačenja Pisma u Aleksandriji i Antiohiji. U zadnjem dijelu članka, na osnovu nekih lekcija iz patristike, predlaže se revizija prakse tumačenja Pisma među evanđeoskim kršćanima. Naročito, evanđeoski kršćani trebali bi: i dalje smatrati Bibliju jedinim nepogrešivim izvorom kršćanske doktrine, nastaviti razvijati povijesno-gramatičku metodu, posebice u odnosu na pitanje analogije vjere u egzegetskom procesu, ali jednako tako bi trebali prepoznati da Biblija ne može u cijelosti imati ulogu pravila vjere ili analogije vjere. Ovome svemu mora se pridružiti još nešto, a to nešto drugo bi trebalo biti otkrivanje patritičkog razdoblja kao ,jedne vrste doktrinarnog kanona“.
\end{abstract}

